\title{
SENSITIVITY TESTS AS A MEANS OF DISTINGUISHING RELAPSE FROM RE-INFECTION \\ IN THE TREATMENT OF GONORRHOEA*
}

\author{
BY \\ H. C. GJESSING AND K. ÖDEGAARD \\ From the Bureau of Public Health, Department of Venereal Diseases (Head: H. C. Gjessing, M.D.) \\ and \\ The State Institute of Public Health, Department of Bacteriology (Head: R. Saxholm, M.D.), Oslo, Norway
}

To assess the efficacy of the treatment of gonorrhoea it is important to distinguish as far as possible between relapse and re-infection in the follow-up period, because re-infection is not due to failure of treatment.

Post-treatment gonorrhoea or relapse generally occurs within 1 or 2 weeks of treatment. Suspicion of re-infection increases with the length of the gonococcus-free interval between the completion of treatment and the new demonstration of the gonococcus. When the patient admits sexual intercourse during the follow-up period and the symptoms appear at the appropriate time, re-infection is indicated (Table I).

TABLE I

PATTERN OF RE-INFECTION

\begin{tabular}{|c|c|c|}
\hline \multirow{4}{*}{ Day } & 1 & Treatment \\
\hline & $\begin{array}{r}7 \\
14\end{array}$ & \} Re-examination $\{$ Gonococci absent \\
\hline & 15 & Re-infection \\
\hline & 21 & New demonstration of gonococci \\
\hline
\end{tabular}

When fresh exposure occurs just after treatment, the return of symptoms may be due to re-infection, but may equally be due to relapse, and such cases should usually be considered as relapses. Summing up, it may be said that, by means of regular clinical and microscopical re-examinations and historytaking, it is often possible to determine with great probability whether relapse or re-infection has caused the recurrence of symptoms.

Since the introduction of the gonococcal sensitivity tests it seems possible in some cases to decide this question with a still greater degree of certainty (Reyn, Korner, and Bentzon, 1958).

At present it is generally accepted that after un-

\footnotetext{
* Received for publication February 2, 1961
}

successful treatment with penicillin the gonococci may either become less sensitive or their sensitivity may remain unchanged. Assuming that this conception is correct, we must conclude that a strain of gonococci which at the first examination has a minimum inhibitory concentration of e.g. 0.5 units $/ \mathrm{ml}$. penicillin, is not identical with a strain which at a later examination has a sensitivity of e.g. 0.03 units $/ \mathrm{ml}$. The prerequisites for such a conclusion are that the technique is unchanged throughout the study, and that the results are judged by the same persons.

\section{Technical Methods}

Specimens of urethral discharge in which gonococci had been demonstrated by direct microscopy were collected on charcoal-impregnated swabs and brought to the laboratory in a modified Stuart's transport medium (Ringertz, 1960). The gonococci were cultivated in the ordinary way on heated blood "chocolate" agar. The diagnostic criteria were: typical oxidase-positive colonies consisting of Gram-negative diplococci, no growth on meat extract agar, acid formation from dextrose but not from maltose and sucrose.

Plate Dilution Sensitivity Test.-Doubling dilutions of crystalline penicillin $G$ were used to give range of penicillin concentration in "chocolate" agar plates from 1 to 0.0075 units $/ \mathrm{ml}$. Thus eight plates, and one control plate without penicillin, were used for each determination. A loopful ( $2 \mathrm{~mm}$. in diameter) collected from several 18 to 20-hour-old colonies on "chocolate" agar, was suspended in $0.5 \mathrm{ml}$. saline. One loopful was removed from this suspension ard inoculated on to the plates. One to four strains of gonococci and staphylococcus strain P 209 were spread on each plate. The staphylococcus strain was used as a control of the penicillin content in the plates. Incubation was carried out at $37^{\circ} \mathrm{C}$. in a humid atmosphere containing carbon dioxide, readings being made after about $20 \mathrm{hrs}$. The sensitivity of the gonococci to penicillin was registered as the minimum concentration at which no growth could be observed by the naked eye. 
Paper Disc Test.-Paper discs of $6 \mathrm{~mm}$. diameter, prepared by the Bacteriological Department, Karolinska Sjukhuset, Stockholm (Ericsson, 1960), were used on "chocolate" agar plates, one disc for each drug, five drugs in all. The amount of antibiotics in the respective discs were: 20 units crystalline penicillin G, $50 \mu \mathrm{g}$. streptomycin, $50 \mu \mathrm{g}$. tetracycline, $50 \mu \mathrm{g}$. chloramphenicol, and $2.4 \mathrm{mg}$. sulphonamide. Several colonies from a culture about $20 \mathrm{hrs}$ old were spread evenly on the plates. The different discs were placed on the plates which then were incubated. Readings were made after about $20 \mathrm{hrs}$. The inhibition zones were measured in $\mathrm{mm}$., and according to size the following designations were used: I sensitive, II fairly sensitive, III slightly sensitive, IV resistant. Because the medium contains elements that may neutralize the action of sulphonamides, the consequence can be a spuriously decreased sensitivity. Therefore we disregard the result of the sulphonamide test in the following.

Although the plate dilution sensitivity test with penicillin is a fairly exact method, it is not sensitive enough to permit a conclusion from a change of only one degree in the scale. At present a difference of at least three degrees in the dilution scale is required to draw a safe conclusion.

In the following, the word resistance is not used in the absolute sense of the word, but to designate a markedly decreased sensitivity, and sensitivity to designate a very high degree of sensitivity.

From a theoretical point of view it may be imagined that a resistant strain can be transformed to a sensitive one by mutation or some other cause. Such a development would be welcome in the treatment of gonorrhoea, but cannot be expected, and this possibility is therefore disregarded for the present.

\section{Discussion}

We observed some instances that correspond to Pattern $a$ in Table II, of which Case 1 is an example.

TABLE II

PATTERN OF SENSITIVITY OF GONOCOCCI TO PENICILLIN IN REGARD TO RELAPSE AND RE-INFECTION

\begin{tabular}{|c|c|c|c|c|c|}
\hline \multicolumn{2}{|c|}{ Pattern } & $a$ & $b$ & $c$ & $d$ \\
\hline Demonst- & First & Resistance & Sensitivity & Sensitivity & Resistance \\
\hline $\begin{array}{l}\text { ration of } \\
\text { Gonococci }\end{array}$ & Second & Sensitivity & Resistance & Sensitivity & Resistance \\
\hline$\overline{\text { Conclusion }}$ & .. & $\begin{array}{l}\text { Re- } \\
\text { infection }\end{array}$ & $\begin{array}{l}\text { Re- } \\
\text { infection? }\end{array}$ & $\begin{array}{l}\text { Re- } \\
\text { infection? } \\
\text { Relapse? }\end{array}$ & Relapse? \\
\hline
\end{tabular}

Case 1 (male).-On September 10 gonococci were present.

Treatment.-Procaine penicillin 600,000 units.

Sensitivity Tests:

Dilution: Penicillin 0.50 units $/ \mathrm{ml}$.

Paper Disc: Penicillin II, Sulphonamide II, Streptomycin II, Chloromycetin I, Tetracycline I.
He did not come for re-examination once a week as ordered, but returned on October 8 with a fresh discharge wherein gonococci were demonstrated. He had felt perfectly well after treatment and was sure he was cured. $\mathrm{He}$ admitted sexual intercourse during the follow-up period.

New sensitivity tests (October 8 ) showed considerable sensitivity to penicillin, viz. 0.03 units $/ \mathrm{ml}$. The sensitivities measured with the paper disc method were Penicillin I, Sulphonamide IV, Streptomycin I, Chloromycetin I, Tetracycline I.

He was re-treated on October 8 with 600,000 units procaine penicillin, and when he was re-examined on October 17 and November 14 no gonococci were found.

It is a weak point in the argument that the patient was not re-examined between the first and second demonstration of gonococci, but the great change from resistance to pronounced sensitivity indicates re-infection. The case history strengthens this view.

Pattern $b$ in Table II is exemplified in Case 2.

Case 2 (male).-On January 3 gonococci were present.

Sensitivity Tests:

Dilution: Penicillin 0.06 units $/ \mathrm{ml}$.

Paper Disc: Penicillin I, Sulphonamide IV, Streptomycin I, Chloromycetin I, Tetracycline I.

Treatment.-Procaine penicillin 600,000 units.

He was re-examined on January 10 and 17 with negative results, but returned on February 6 with a fresh urethral discharge wherein gonococci were demonstrated. He admitted sexual intercourse on February 2.

New sensitivity tests showed that the inhibitory concentration of penicillin was 0.50 units $/ \mathrm{ml}$. The paper disc test indicated that the sensitivity of the gonococci was penicillin II and the other drugs employed I.

It seems rather improbable that resistance should develop so soon after treatment with penicillin, and the change in the sensitivity pattern therefore indicates re-infection, and the case history supports this view. This reasoning does not apply to all antibiotics, especially not the streptomycin to which a decrease in sensitivity may develop very rapidly.

Patterns $c$ and $d$ give no information as to relapse or re-infection, and the sensitivity pattern has to be judged together with the case history. Case 3 conforms to Pattern $c$.

Case 3 (male).-This patient was treated on August 15 with procaine penicillin 600,000 units, and returned on August 26 with gonococci in the discharge. Because further sexual intercourse was at first denied, this case was interpreted as one of failure of treatment and he was given 1 g. streptomycin.

Sensitivity Tests:

Dilution: Penicillin 0.015 units $/ \mathrm{ml}$.

Paper Disc: Penicillin I, Sulphonamide IV, Streptomycin II, Chloromycetin I, Tetracycline I. 
The patient was re-examined on September 2, 7, and 14 , when the findings were negative. He had sexual intercourse on September 17, which he at first denied.

He returned to the clinic on September 21 with a urethral discharge, in which gonococci were found. He then admitted sexual relations with the original source of infection after the first as well as after the second treatment. The dose of procaine penicillin 600,000 units was repeated and the sensitivity tests were performed once more. With the exception that the inhibitory concentration of penicillin was now 0.03 units $/ \mathrm{ml}$., the results of the tests were exactly the same as the first time. The patient was re-examined and found to be negative during a period of 31 days after the completion of treatment.

By comparing the first and second sensitivity tests we get no clue as to relapse or re-infection, but the case history makes this an obvious case of reinfection. The practically unchanged result of the tests is also in accordance with the probability that he was infected three times by the same woman.

Pattern $d$ is a variation or a special form of pattern $c$. Preliminary statistics from Oslo show that 10 per cent. of the gonococci examined now have a resistance of 0.50 units $/ \mathrm{ml}$. penicillin and consequently the chance of re-infection with a new strain of the same resistance is only 10 per cent., whereas the chance of relapse is 90 per cent. Furthermore, we know that treatment failure very often occurs in strains with this high degree of resistance. Therefore cases characterized by a markedly decreased sensitivity ought to be considered as relapses, provided the case history does not afford special information to the contrary.

Case 4 is a typical example of post-treatment gonorrhoea.

Case 4 (male). - On November 4 gonococci were found in the urethral discharge.

Treatment: 600,000 units procaine penicillin.

Sensitivity Tests:

Dilution: Inhibitory concentration of penicillin $\mathbf{0} \cdot 50$ units $/ \mathrm{ml}$.

Paper Disc: Penicillin II, Sulphonamide II, Streptomycin IV, Chloromycetin I, Tetracycline I.

On November 7 gonococci present in discharge, and a specimen was taken for new sensitivity tests, the result of which was exactly the same as the first. Because we had not yet received the answer the patient was treated with 1 g. streptomycin. He returned on November 12 again with gonococci in the discharge. At that time we had received the result of the first sensitivity tests, in consequence of which he was given Terramycin $250 \mathrm{mg} . \times 32$. After the completion of treatment he was re-examined five times during a period of $\mathbf{4 2}$ days and gonococci were not demonstrated.

\section{Summary}

According to the theory-or the probabilitythat a strain of gonococci, cannot change from resistance to sensitivity to penicillin, it may be supposed that the diagnosis of re-infection can sometimes be made by means of sensitivity tests. When the gonococci at the first examination are resistant (e.g. the inhibitory concentration of penicillin is 0.50 units $/ \mathrm{ml}$.) and the gonococci at a reexamination 2 or 3 weeks later are very sensitive (e.g. to 0.03 units $/ \mathrm{ml}$.), two different strains must be involved, indicating re-infection.

It is assumed that a difference of at least three degrees in the dilution scale is needed to draw a safe conclusion. The opposite case, high sensitivity (e.g. to 0.03 units $/ \mathrm{ml}$.) followed by resistance (e.g. to 0.50 units $/ \mathrm{ml}$.) 2 or 3 weeks later, also indicates re-infection.

The sensitivity tests alone give no information regarding relapse or re-infection if the results are about the same at consecutive examinations. In such instances the result must be judged in the light of the clinical examination and case history.

The paper disc tests with streptomycin, chloramphenicol, and tetracycline may also be useful. If the sensitivity pattern is completely changed at a second examination of a patient treated with penicillin only, re-infection is indicated.

The paper disc tests can be very useful when it is a question of finding the right drug after penicillin treatment has failed.

Four cases illustrating four different sensitivity patterns are described.

\section{REFERENCES}

Ericsson, H. (1960). Scand. J. clin. Lab. Invest., 12, Suppl. 50.

Reyn, A., Korner, B., and Bentzon, M. W. (1958). Brit. J. vener. Dis., 34, 227.

Ringertz, O. (1960). Acta path. microbiol. Scand., 48, 105.

Les épreuves de la sensibilité pour distinguer les rechutes des ré-infections dans le traitement de la blennorragie.

\section{RÉSUMÉ}

Selon la théorie - ou plutôt la probabilité - qu'une souche gonococcique qui résiste à la pénicilline ne peut pas y devenir sensible, on peut croire que le diagnostic des ré-infections pourrait être établi par les épreuves de la sensibilité.

Quand une souche est résistante à première vue (c'està-dire que la concentration inhibitrice de la pénicilline 
est 0,50 unités par mi.) et puis, après 2 or 3 semaines, elle se montre sensible à une concentration de 0,03 unités par ml., il doit s'agir de deux souches différentes, c'està-dire d'une ré-infection.

D'ailleurs une sensibilité marquée (à 0,03 unités $/ \mathrm{ml}$.) suivie d'une résistance (à 0.50 unités $/ \mathrm{ml}$.) indique également une ré-infection.

On suppose qu'une différence de 3 degrés de dilution au moins est nécessaire pour tirer une conclusion définitive. Cependant les épreuves de la sensibilité seules ne donnent aucune réponse à la question de ré-infection ou de rechute si les résultats des examens consecutifs sont à peu près semblables.

Les épreuves de la streptomycine, le chloramphenicol, et la tétracycline à plaques de papier peuvent être également utiles. Si le degré de sensibilité varie au second examen d'un malade traité avec la pénicilline, on doit soupçonner une ré-infection; d'ailleurs ces tests aident à choisir le meilleur médicament quand la pénicilline a échoué.

On décrit quatre exemples de différents types de sensibilit:. 